\title{
Perencanaan Sistem Instalasi Plambing Air Bersih dengan Penerapan Alat Plambing Hemat Air Di Rumah Sakit Universitas Sam Ratulangi
}

\author{
Adeyra Khairunisa Rahayu ${ }^{1 *}$, Yulianti Pratama², Anindito Nurprabowo ${ }^{3}$ \\ 1,2,3 Jurusan Teknik Lingkungan, Fakultas Teknik Sipil dan Perencanaan, Institut Teknologi Nasional Bandung \\ Jl. PHH Mustofa No. 23, Bandung, 40124, Indonesia \\ *Koresponden email: adeyrahayu@gmail.com
}

Diterima: 27 Desember 2019

Disetujui: 30 Januari 2020

\begin{abstract}
The hospital is a health service building, a place of transmission of disease and allows environmental pollution and health problems. One of the prevention of disease transmission and environmental pollution, it is necessary to do repairs and improvements by using a plumbing system to have good sanitation and environmental friendly. In this case, needed to know how much water can save by method comparing between plumbing tools conventional and non-conventional standar. UNSRAT's hospital has a population of 2,962 people who needed clean water distribution of $372,48 \mathrm{~m}^{3} /$ day. Compared by using conventional plumbing tools is $66,72 \mathrm{~m}^{3} /$ hari, meanwhile non-conventional plumbing tools is 39,60 $\mathrm{m}^{3} /$ hari, it shown that using non-conventional plumbing tools standard is more saving than conventional standard, where percentage non-conventional water saving is $40,64 \%$. Also expected that the resulting domestic wastewater will be reduced by $31,68 \mathrm{~m}^{3} /$ day. This is more important than water savings in the amount of Rp. 3.564.000 and domestic wastewater treatment costs Rp. 9.500.000.
\end{abstract}

Keywords: Plumbing, plumbing tools, plumbing comparison, plumbing instalation, water saving

\begin{abstract}
Abstrak
Rumah sakit merupakan sarana pelayanan kesehatan, dimana memungkinkan terjadinya pencemaran lingkungan dan gangguan kesehatan, salah satu upaya untuk mencegah hal tersebut perlu adanya sanitasi pada rumah sakit. Maka dari itu, perencanaan sistem plambing hemat air ang bertujuan agar terwujudnya sanitasi yang baik dan ramah lingkungan. Penelitian ini bertujuan untuk mengetahui seberapa hemat penggunaan alat plambing tersebut dengan metode yang dilakukan yaitu membandingkan standar pemakaian air alat plambing konvensional dan non-konvensional. Rumah Sakit UNSRAT memiliki jumlah populasi sebanyak 2.962 orang sehingga diperlukan penyaluran air bersih sebesar $372,48 \mathrm{~m}^{3} / \mathrm{hari}$. Perbandingannya pemakaian air pada alat plambing konvensional yaitu $66,72 \mathrm{~m}^{3} /$ hari sedangkan pemakaian air alat plambing non-konvensional yaitu $39,60 \mathrm{~m}^{3} /$ hari, dari perbandingan tersebut menunjukkan bahwa pemakaian air menggunakan alat plambing non-konvensional lebih kecil dibandingkan standar alat plambing konvensional dimana persentase penghematan mencapai 40,64\% . Sehingga penggunaan alat plambing non-konvensional pula berpengaruh pada debit air limbah yang dihasilkan berkurang sebanyak $31,68 \mathrm{~m}^{3} /$ hari. Hal tersebut pun berpengaruh terhadap biaya penghematan air yaitu berkurang sebesar Rp. 3.564.000 dan biaya pengolahan air limbah domestik berkurang Rp. 9.504.000.
\end{abstract}

Kata Kunci : Plumbing, alat plambing, perbandingan plumbing, instalasi plumbing, hemat air, hospital

\section{Pendahuluan}

Rumah sakit merupakan sarana pelayanan kesehatan, tempat berkumpulnya baik orang sakit maupun orang sehat, di rumah sakit juga memungkinkan terjadinya pencemaran lingkungan dan gangguan kesehatan [1]. Salah satu pencegahan penularan penyakit dan pencemaran lingkungan di rumah sakit, perlu adanya sanitasi yang baik yaitu dengan direncanakannya sistem plambing. Menurut [2] plambing merupakan sistem teknologi pemipaan dan peralatan untuk menyediakan air bersih ke tempat yang diinginkan dengan kontinuitas yang memenuhi syarat dan membuang air limbah dari tempat tertentu tanpa mencemari sekitar, sehingga mampu menciptakan kondisi yang higienis dan nyaman. 
Rumah Sakit Akademik Universitas Sam Ratulangi (RSA UNSRAT) Kota Manado memiliki luas bangunan sebesar $5.574 \mathrm{~m}^{2}$ dan terdiri dari tiga Blok, terdapat 7 lantai pada Blok A dan Blok B1. Sumber air bersih untuk kebutuhan RSA UNSRAT diperoleh dari PDAM setempat. Hal ini sesuai dengan [3] tentang Bangunan Gedung yang menyatakan bahwa suatu bangunan harus memenuhi persyaratan sistem sanitasi, dengan dilengkapinya air bersih dan penyaluran air limbah. Oleh karena itu perencanaan sistem instalasi plambing pada RSA UNSRAT wajib memenuhi persyaratan sistem sanitasi.

Dalam mewujudkan perencanaan dan perancangan bangunan berkelanjutan yang efisien dalam penggunaan sumber daya, maka RSA UNSRAT menerapkan Bangunan Hijau [4] yang mengacu pada Peraturan Menteri Pekerjaan Umum dan Perumahan Rakyat Nomor 2 Tahun 2012 tentang Bangunan Gedung Hijau [5] dimana upaya penerapan Bangunan Hijau tersebut yang dapat dilakukan yaitu salah satunya efisiensi air dengan penggunaan alat plambing hemat air. Sehingga penerapan Bangunan Hijau di RSA UNSRAT ini diharapkan mampu untuk memadai penggunaan air secara efisien dengan bantuan pemasangan alat plambing hemat air, seperti halnya pada salah satu bangunan resort di Kota Bandung yang juga menerapkan penggunaan alat plambing hemat air yang mampu menghemat sebesar 80,64\% [6].

\section{Metodologi Penelitian}

Teknik analisis data yang digunakan dalam perencanaan ini yaitu dilakukan studi literatur, kemudian pengumpulan data, yang mana data yang diambil yaitu data sekunder seperti denah gedung RSA UNSRAT, selanjutnya dilakukan perencanaan teknis dimana perencanaan teknis ini menentukan jumlah populasi pada gedung, penentuan pemakaian air per hari pada setiap jenis alat plambing baik konvensional maupun non-konvensional, sehingga selanjutnya dapat diketahui perbandingan persentase hemat air, untuk lebih jelasnya dapat dilihat pada alur perencanaan Gambar 1.

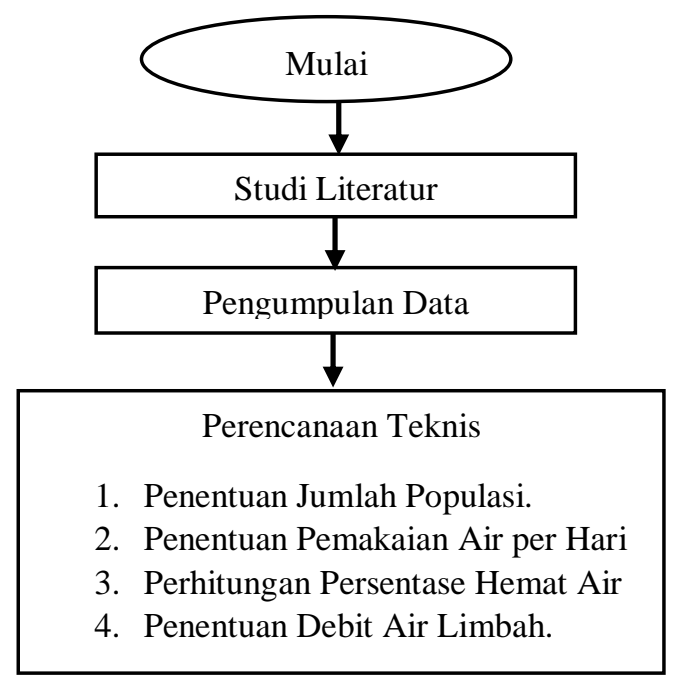

Gambar 1. Alur perencanaan penelitian

\section{Perhitungan Jumlah Populasi}

Perhitungan jumlah populasi dilakukan untuk mengetahui kebutuhan air bersih di setiap lantainya berdasarkan fungsi ruang. Penentuan jumlah populasi tersebut menggunakan persamaan yang merujuk pada Ref. [2] yaitu:

$$
\text { Jumlah populasi }=\frac{\text { Luas efektif }(\%) x \text { Luas Lantai }\left(m^{2}\right)}{\text { Standar beban hunian }}=\text { Luas efektif \% } x \text { Luas Lantai }\left(m^{2}\right) / \text { standar beban hunian....(1) }
$$

Namun untuk rumah sakit dapat diketahui jumlah populasi pada setiap fungsi ruangnya berdasarkan Pedoman Teknis Rumah Sakit Kelas B [14]. Namun bila fungsi ruang tidak tercantum pada pedoman maka perlu dilakukan perhitungan dengan persamaan 1. Kemudian pada setiap jenis alat plambing memiliki persen okupansi yang berbeda-beda sehingga setelah mengetahui jumlah populasi yang dimiliki dikalikan dengan persen okupansi pada setiap jenis alat plambing, dimana standar persen okupansi didapatkan dari GBCI. 


\section{Penentuan Pemakaian Air}

Berdasarkan jumlah populasi yang dimiliki dapat ditentukan pemakaian air yang dibutuhkan oleh setiap jenis alat plambing baik konvensional maupun non-konvensional, yaitu dilakukan perhitungan dengan persamaan 2 berikut:

Pemakaian Air $=$

Jumlah Populasi x Durasi Pemakaian Air x Debit Pemakaian Air x Faktor Pemakaian Air

Durasi dan debit pemakaian air tersebut memiliki standar yang berbeda pada setiap jenis alat plambing, yang mana standar tersebut mengacu pada Green Building Council Indonesia.

\section{Persentase Penghematan Air}

Persentase penghematan air ini diperlukan untuk mengetahui berapa besaran air yang dihemat setelah menggunakan alat plambing hemat air. Persentase penghematan air dapat dihitung menggunakan rumus sebagai berikut :

$$
\text { Persentase } \%=\frac{\text { Kebutuhan Air Bersih (alat plambing hemat air) }}{\text { Kebutuhan Air Bersih }} \times 100 \%
$$

\section{Debit Air Limbah}

Air limbah domestik terbagi menjadi dua yaitu greywater dan blackwater, untuk mengetahui debit air limbah yang dihasilkan berdasarkan debit kebutuhan air bersih yang sudah diperhitungkan. Persentase yang dihasilkan pada air limbah yaitu 80\% [7] untuk menghitung debit air limbah dapat menggunakan rumus sebagai berikut:

$$
Q \text { air limbah }\left(\mathrm{m}^{3} / \text { hari }\right)=80 \% \times \text { total kebutuhan air bersih } .
$$

\section{Hasil dan Pembahasan}

Penentuan jumlah populasi pada perencanaan sistem plambing [8] merupakan hal terpenting, dimana jumlah populasi akan menentukan kebutuhan air bersih dan jumlah alat plambing yang harus dipasang. Jumlah populasi pada Blok A dan Blok B1 di RSA UNSRAT yaitu 1.792 orang. Penentuan jumlah populasi ini berdasarkan Pedoman Rumah Sakit Kelas B dan data arsitek [9] yang dibagi atas beberapa jenis populasi seperti dokter, perawat, co-ass, karyawan, mahasiswa dan pengunjung. Hasil rekapitulasi populasi yang terdapat di Blok A dan Blok B1 RSA UNSRAT dapat dilihat pada Tabel 1.

Tabel 1. Jumlah populasi orang pada Blok A dan Blok B1 di RSA UNSRAT

\begin{tabular}{ccccccccc}
\hline \multirow{2}{*}{ Lantai } & $\begin{array}{c}\text { Jumlah } \\
\text { Populasi }\end{array}$ & $\begin{array}{c}\text { Pasien } \\
\text { RI* }\end{array}$ & $\begin{array}{c}\text { Pasien } \\
\text { RJ** }\end{array}$ & Dokter & Perawat & Karyawan & Mahasiswa & Pengunjung \\
\hline 1 & 262 & 35 & 14 & 35 & 42 & 88 & - & 47 \\
2 & 291 & 14 & 13 & 51 & 36 & 80 & - & 90 \\
3 & 286 & 121 & 6 & 77 & 55 & 12 & - & 9 \\
4 & 304 & 27 & 22 & 52 & 55 & 90 & 32 & 40 \\
5 & 231 & 16 & - & 43 & 9 & 114 & 20 & 28 \\
6 & 209 & - & - & - & - & 42 & 160 & 14 \\
7 & 209 & - & - & - & - & 42 & 160 & 14 \\
Jumlah & 1792 & 213 & 55 & 331 & 198 & 454 & 372 & 242 \\
\hline
\end{tabular}

Sumber : Hasil pengolahan data [10]

Total alat plambing hemat air yang dipasang pada RSA UNSRAT Blok A dan Blok B1 sebanyak 344 unit, yang terdiri dari water closet, urinal, lavatory, dan shower, dimana setiap jenis alat plambing memiliki kebutuhan air yang berbeda-beda. Penelitian ini menggunakan alat plambing non-konvensional. Pemilihan alat plambing non-konvensional didasari pada ECO System yang memiliki standar kebutuhan air. Perbedaan alam plambing konvensional dan non-konvensional dapat dilihat pada Tabel 2. 
Tabel 2. Kebutuhan air pada alat plambing

\begin{tabular}{ccc}
\hline Alat Plambing & $*$ Kovensional & $* *$ Non-Konvensional \\
\hline water closet tank & 6 Liter/Flush & 6 Liter/Flush \\
urinal & 4 Liter/Flush & 0,47 Liter/Flush \\
lavatory & 8 Liter/menit & 7 Liter/menit \\
shower & $9 \mathrm{Liter} /$ menit & 6 Liter/menit \\
\hline
\end{tabular}

Sumber : GBCI [4] dan [10]

Perhitungan besaran hemat air yang didapatkan dapat diketahui dari standar konsumsi yang mengacu pada Green Building Council Indonesia [4]. Adapun standar konsumsi air untuk alat plambing hemat air dapat dilihat pada Tabel 3.

Tabel 3. Standar konsumsi air

\begin{tabular}{cccc}
\hline Jenis Alat Plambing & Okupansi & Faktor & Satuan \\
\hline WC Wanita & $50 \%$ & 2,3 & Rata-Rata Pemakaian per Orang per Hari \\
WC Pria & $50 \%$ & 0,3 & Rata-Rata Pemakaian per Orang per Hari \\
Urinal & $50 \%$ & 2 & Rata-Rata Pemakaian per Orang per Hari \\
Durasi Cuci Tangan & $100 \%$ & 0,15 & Menit/pemakaian \\
Durasi Pemakaian Shower & $5 \%$ & 5 & Menit/pemakaian \\
Pemakaian Tap & $100 \%$ & 2,5 & Per Hari \\
\hline
\end{tabular}

Sumber : GBCI [4]

\section{Penghematan Air (Non-Konvensional)}

Perhitungan jumlah populasi berdasarkan okupansi alat plambing water closet tank yaitu 2.962 . Nilai tersebut diperoleh dari jumlah populasi 1.792 dikalikan dengan shift pada setiap jenis populasinya. Hasil perhitungan jumlah populasi berdasarkan okupansi dapat dilihat pada Tabel 4.

Tabel 4. Jumlah populasi berdasarkan okupansi

\begin{tabular}{lccc}
\hline \multicolumn{1}{c}{ Fixture Type } & Awal & Populasi & Okupansi \\
\hline WCT & & $50 \%$ & Akhir \\
Urinal & 2.962 & $50 \%$ & 1.481 \\
Lavatory & $100 \%$ & 1.481 \\
Faucet & $100 \%$ & 2.962 \\
Shower & $5 \%$ & 2.962 \\
\hline
\end{tabular}

Sumber : Hasil perhitungan [10]

Hasil perhitungan pemakaian air setelah menggunakan alat plambing dapat dilihat di Tabel $\mathbf{5}$. Perhitungan pemakaian air ini diperoleh dari jumlah populasi okupansi dikalikan dengan durasi pemakaian dan debit standar alat plambing hemat air.

Tabel 5. Pemakaian air (non-konvensional)

\begin{tabular}{cccccccc}
\hline \multirow{2}{*}{ Durasi Pemakaian } & \multicolumn{2}{c}{ Debit } & \multicolumn{2}{c}{ Faktor Pemakaian } & \multicolumn{2}{c}{ Pemakaian } & Pemakaian \\
Faktor & \multicolumn{2}{c}{ Air } \\
Satuan & Besaran & Satuan & Faktor & Satuan & Air (L/Hari) & $\left(\mathrm{m}^{3} /\right.$ Hari) \\
\hline 2,3 & pemakaian/org/hr & 4,5 & L/flush & - & - & $15.328,35$ & 15,33 \\
2 & pemakaian/org/hr & 0,47 & L/flush & - & - & $1.392,14$ & 1,39 \\
0,15 & menit/pemakaian & 7 & L/menit & 2,5 & per hari & $7.775,25$ & 7,77 \\
0,15 & menit/pemakaian & 3,6 & L/menit & 2,5 & per hari & $3.998,70$ & 3,99 \\
5 & menit/pemakaian & 6 & L/menit & 2,5 & per hari & $11.107,50$ & 11,11 \\
& & Total & & & & $39.601,94$ & 39,60 \\
\hline
\end{tabular}

Sumber : Hasil perhitungan [10]

\section{Penghematan Air Konvensional}

Perhitungan kebutuhan air menggunakan alat plambing konvensional setara dengan perhitungan kebutuhan air yang menggunakan alat plambing hemat air. Hasil yang berbeda ditunjukkan pada standar debit air pada alat plambing. Hasil perhitungan pemakaian tanpa hemat air dapat dilihat pada Tabel 6. 
Tabel 6. Pemakaian air konvensional

\begin{tabular}{cccccccc}
\hline \multicolumn{2}{l}{$\begin{array}{c}\text { Durasi Pemakaian } \\
\text { Faktor }\end{array}$} & Sebit & \multicolumn{2}{c}{ Faktor Pemakaian Tap } & \multicolumn{2}{c}{$\begin{array}{c}\text { Pemakaian } \\
\text { Air }\end{array}$} & $\begin{array}{c}\text { Pemakaian } \\
\text { Air }\end{array}$ \\
& Besaran & Satuan & Faktor & Satuan & (L/Hari) & $\left(\mathrm{m}^{3} /\right.$ Hari $)$ \\
\hline 2,3 & pemakaian/org/hr & 6 & L/flush & - & - & $20.437,80$ & 20,44 \\
2 & pemakaian/org/hr & 4 & L/flush & - & - & $11.848,00$ & 11,85 \\
0,15 & menit/pemakaian & 8 & L/menit & 2,5 & per hari & $8.886,00$ & 8,88 \\
0,15 & menit/pemakaian & 8 & L/menit & 2,5 & per hari & $8.886,00$ & 8,88 \\
5 & menit/pemakaian & 9 & L/menit & 2,5 & per hari & $16.661,25$ & 16,66 \\
& & \multicolumn{2}{c}{ Total } & & & $66.719,05$ & 66,72 \\
\hline
\end{tabular}

Sumber : Hasil perhitungan [10]

Tabel 7 menunjukkan hasil perhitungan pemakaian air yang diperoleh berdasarkan perbandingan pemakaian air alat plambing konvensional dan alat plambing non-konvensional dengan perbedaan penghematan air sebanyak $27,12 \mathrm{~m}^{3} /$ hari atau persentase penghematan $40,64 \%$. Sedangkan hasil perhitungan penghematan air dengan neraca air dapat dilihat pada Gambar 2.

Tabel 7. Penghematan air

\begin{tabular}{ccc}
\hline Alat Plambing & Konvensional $\left(\mathrm{m}^{3} /\right.$ hari $)$ & Non-Konvensional $\left(\mathrm{m}^{3} / \mathrm{hari}^{)}\right.$ \\
\hline WCT & 20,44 & 15,33 \\
Urinal & 11,85 & 1,39 \\
Lavatory & 8,88 & 7,77 \\
Faucet & 8,88 & 3,99 \\
Shower & 16,66 & 11,11 \\
Total & 66,72 & 39,60 \\
\hline
\end{tabular}

Sumber : Hasil perhitungan [10]

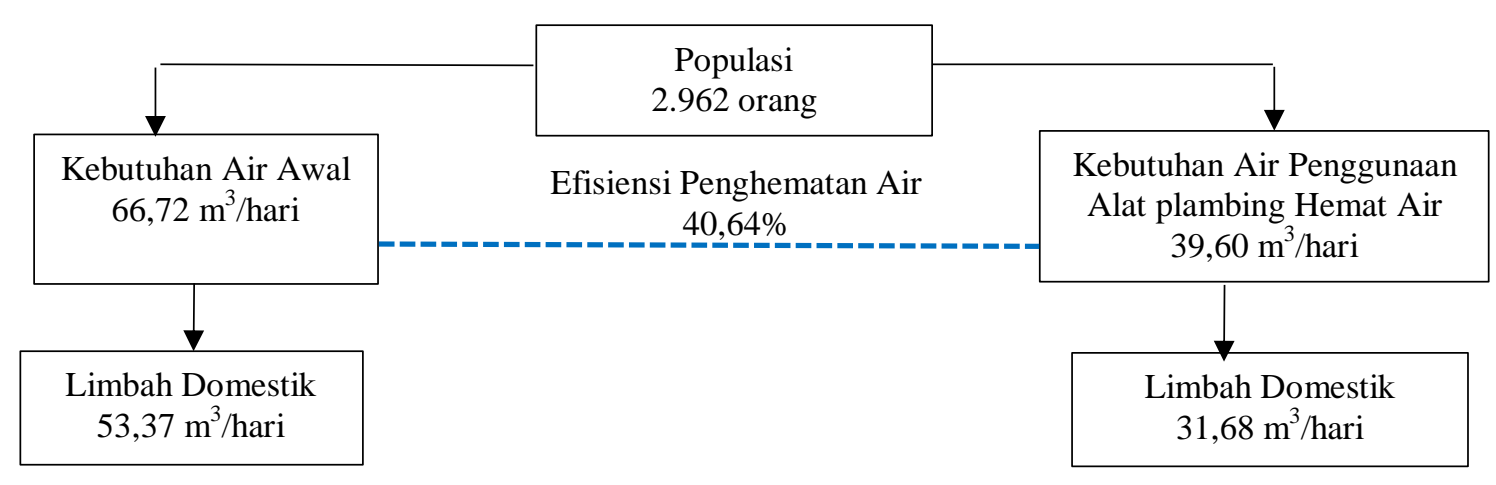

Gambar 2. Neraca air

Selain mampu menghemat penggunaan air tentunya akan mampu menghemat biaya penggunaan air. Kota Manado memiliki standar biaya penggunaan air per bulan nya yaitu untuk rumah sakit pemerintah masuk pada Golongan II dengan debit $>20 \mathrm{~m}^{3}$ yaitu Rp. $3.000 / \mathrm{m}^{3}$, sehingga dengan hemat air sebesar 39,60 $\mathrm{m}^{3} /$ hari dan jumlah populasi 2.962 orang, maka biaya penggunaan air hemat sebesar Rp. 3.564.000/bulan dibandingkan dengan penggunaan alat plambing konvensional yaitu sebesar Rp. 6.004.800. Selain itu terdapat pula biaya pengolahan air limbah cair beserta lumpurnya oleh PT. Harum Tirta Jaya[15]. Biaya Instalasi Pengolahan Air Limbah Rumah Sakit yaitu Rp. 10.000/m ${ }^{3}$, jika limbah cair domestik yang dihasilkan berkurang $31,68 \mathrm{~m}^{3} /$ hari setelah menggunakan alat plambing hemat air maka biaya pengolahan IPAL hemat sebesar Rp. 9.504.000/bulan, atau lebih jelasnya dapat dilihat pada Tabel 8.

Tabel 8. Biaya dari alat plambing hemat air

\begin{tabular}{lc}
\hline \multicolumn{1}{c}{ Biaya Alat Plambing } & Harga (per Bulan) \\
\hline Biaya Penghematan Air & Rp. 3.564.000 \\
Biaya Pengolahan Limbah Cair & Rp. 9.504 .000 \\
Domestik & \\
\hline
\end{tabular}

Sumber : [15] 
Sebagai perbandingan, gedung sekolah Olifant School [11] yang memiliki jumlah populasi 590 orang yang mampu menghemat air sebesar 47\%, bangunan apartemen Menara Cibinong [12] yang berpopulasi 1.322 orang menghemat air sebesar 33\%. Maka persentase efisiensi penghematan air tersebut cenderung tidak terlalu jauh dengan persentase efisiensi penghematan air di RSA UNSRAT Kota Manado. Perbandingan kedua jenis bangunan berdasarkan kadar penghematan air dapat dilihat pada Tabel 9.

Tabel 9. Perbandingan efisiensi penghematan air dari jenis bangunan

\begin{tabular}{lcc}
\hline \multicolumn{1}{c}{ Jenis Bangunan } & $\begin{array}{c}\text { Jumlah Populasi } \\
\text { (Orang) }\end{array}$ & $\begin{array}{c}\text { Efisiensi Penghematan Air } \\
(\%)\end{array}$ \\
\hline Rumah Sakit Akademik UNSRAT & 2.962 & 40,64 \\
Sekolah & 590 & 47 \\
Apartmen & 1.322 & 33 \\
\hline \multicolumn{3}{c}{ Sumber : [10] }
\end{tabular}

\section{Kesimpulan}

Perencanaan sistem plambing [13] di RSA UNSRAT pada Blok A dan Blok B1 memiliki kebutuhan air bersih awal $66,72 \mathrm{~m}^{3} /$ hari, pada perencanaan ini diterapkan green building. Pemasangan alat plambing hemat air nenghasilkan efisiensi penghematan air sebesar 40,64\% atau mampu menghemat air sebesar $27,12 \mathrm{~m}^{3} /$ hari. Dari pemakaian awal $66,72 \mathrm{~m}^{3} /$ hari menjadi $31,68 \mathrm{~m}^{3} /$ hari, dan limbah domestik yang dihasilkan berkurang $31,68 \mathrm{~m}^{3} /$ hari, sehingga mampu menghemat biaya penggunaan air sebesar Rp. 3.564.000 dan biaya pengolahan air limbah domestik beserta lumpurnya yaitu Rp. 9.504.000.

\section{Singkatan}

$\begin{array}{ll}\text { Pasien RJ } & \text { Pasien Rawat Jalan } \\ \text { Pasien RI } & \text { Pasien Rawat Inap } \\ \text { GBCI } & \text { Green Building Council Indonesia }\end{array}$

\section{Referensi}

[1] Departemen Kesehatan Republik Indonesia, Pedoman Sanitasi Rumah Sakit di Indonesia. Jakarta: Direktoral Jenderal PPM \& PPL dan Direktorat Jenderal Pelayanan Medik, 2004.

[2] Noerbambang, S. Moh, dan T. Morimura, Perancangan dan Pemeliharaan Sistem Plambing, Jakarta : Pradnya Paramita, 2000.

[3] Peraturan Daerah Kota Manado Nomor 6 Tahun 2012 tentang Bangunan Gedung.

[4] Green Building Council Indonesia, Greenship Rating Tools: Greenship for the New Building version 1.1, Summary of Criteria and Benchmarks, 2013.

[5] Peraturan Menteri Pekerjaan Umum dan Perumahan Rakyat Nomor 2 Tahun 2012 tentang Bangunan Gedung Hijau.

[6] Rinka, D.Y, "Perencanaan Sistem Plambing Air Limbah dengan Penerapan Konsep Green Building pada Gedung Panghegar Resort Dago Golf-Hotel and Spa," Jurnal Reka Lingkungan, 2014.

[7] Hardjosuprapto, M, Penyaluran Air Buangan Volume 1, ITB : Bandung, 2000.

[8] SNI 7065 - 2005, Tata Cara Perencanaan Sistem Plambing, Jakarta : BSN, 2005

[9] Ernst dan Neufert P, Data Arsitek Jilid 2, Erlangga, Jakarta, 1993.

[10] TOTO Indonesia Katalog (2019). Fittings, Sanitary Wales, and Accessoris. Diakses 11 November 2019, dari https://www.toto.co.id.

[11] Annisa Dwi Safiyanti, "Perencanaan Sistem Instalasi Plambing Air Bersih Gedung Olifant School," Jurnal Reka Lingkungan, 2018.

[12] Wahyudi, The Use of Plumbing Tools savung water With Efforts to Save Clean Water with Application of Green Building Concept at Menara Cibinong Apartment, ICGTD Itenas, 2019.

[13] SNI 8153 - 2015, Sistem Plambing Pada Bangunan Gedung, Jakarta: BSN, 2015.

[14] Direktorat Bina Pelayanan Penunjang Medik dan Sarana Kesehatan Direktorat Bina Upaya Kesehatan Kementerian Kesehatan Republik Indonesia Tahun 2012 Tentang Pedoman Teknis Bangunan Rumah Sakit Kelas B, 2012.

[15] PT. Harum Tirta Jaya. (2018). Instalasi Pengolahan Air Limbah Rumah Sakit. Diakses 12 Desember 2019, dari https://www.harumtirtajaya.com 